\title{
Sediments and the EU-Water Framework Directive: revisiting the Elbe 2015 River Basin Management Plan
}

\author{
Ulrich Förstner $^{1,2}$
}

Received: 8 July 2015 / Accepted: 12 July 2015 / Published online: 26 July 2015

(C) Springer-Verlag Berlin Heidelberg 2015

According to Förstner (2002), p. 54 "The [EU] WFD aims at achieving a good ecological potential and good surface water chemical status in European river basins until the year 2015 by a combined approach using emission and pollutant standards. These consider priority pollutants from diffuse and point sources, but neglect the role of sediments as a longterm secondary source of contaminants. Such a lack of information may easily lead to unreliable risk analyses with respect to the - pretended - 'good status"'. Now, with the Actualized River Basin Management Plan (RBMP) of the Elbe (RBC Elbe 2014), it is official that "without goaloriented measures for the reduction of primary and secondary pollution sources, the objectives of a good chemical and ecological quality in surface waters until the end of the second management period (of the WFD) and a good environmental state according to the [EU] Marine Strategy Framework Directive (MSFD) until 2020 will be strongly endangered". Which raises the important question: why not point directly to the basic reasons for this failure? The River Basin Community (RBC) of the Elbe has exemplarily developed an understanding of "historical contaminated sediments" e.g. (RBC Elbe 2009). On the other hand, the typical Elbe issue of "dioxins" was neglected during the first WFD phase. In the period 2016-2021, dioxins/furans + dl-PCB will play a major role: (i) as new priority substances in the list of biotaenvironmental quality standards (EQS), (ii) as indicator

Ulrich Förstner

u.foerstner@tu-harburg.de

1 University of Technology Hamburg-Harburg, Institute of Environmental Technology and Energy Economics, Eissendorfer Str, 21071 Hamburg, Germany

2 Stöversweg 6a, 21244 Buchholz, Germany substances at the land-sea interface (i.e. the interface between WFD and MSFD), and (iii) for solutions to advanced technical problems (Förstner 2015a).

At first, the Actualized RBMP for the Elbe declared that none of the water bodies in the German part of the Elbe River basin will reach the level of a "good chemical state"-mainly due to the catchment-wide exceedance of the EQS of mercury in biota (RBC Elbe 2014). Directive 2013/39/EC (from August 24, 2013) reflects the latest development referring to newly identified priority substances such as dioxins and dioxin-like PCB compounds; here too, the relevance of the biota-EQS criterion for a target achievement is high, as has been proven from the study of environmental specimen bank organisms (e.g. fish, molluscs and crustaceans), where the EQS value of $0.0065 \mu \mathrm{g}$ TEQ $\mathrm{kg}^{-1}$ for dioxin was exceeded by $>50 \%$ of the tested specimens (Mohaupt et al. no date).

The MSFD 2008/56/EC (from June 17, 2008) is similar to the WFD, in its stepwise implementation mode and with its main objective in the achievement of good environmental status (GES) in the marine environment by 2020. The MSFD also takes account of land-based and fluvial aspects and ensures comparable approaches and methodologies as in WFD. All of these should be indications for a mandate to the RBC Elbe; however, no activities at the land-sea interface are reported in the Actualized RBMP (RBC Elbe 2014). It seems that the situation has even worsened. For example, SaxonyAnhalt's Agency for Contaminated Sites has banned the term "dioxin" from various documents (Förstner 2015b), and Hamburg together with the other German North Sea Laender (or States) renewed the exclusion of dioxin from the list of pollutants to be considered in the handling of dredged materials in coastal waters (Anon 2009/2013). 
A third complex legal approach in support of the chemical quality under the WFD is an assessment and management of flood risks, following Directive 2007/60/EC; the special role of sediment-bound contaminants is due to the exponential increase of solid/pollutant loads with higher water velocities. The assessment of erosion stabilities was one of the major achievements of the Sediment Management Concept of the RBC-Elbe (RBC Elbe 2013); another was the development of criteria for the priorization of measures.

At the end, the Elbe RBMP was called a "success" by the RBC-Elbe, when the Tauw Study (Jacobs et al. 2013) on pollutant load reduction in the Spittelwasser Creek, Germany, assumed that the summer flood of 2002 must have eroded the most critical dioxin hot spots downstream from the Bitterfeld region. However, our evaluation of radiometric maps from near the river banks indicates that there are still significant amounts of dioxins in $\sim 10-20$ ha of surface-exposed sediments/fluvisols at this site. These findings could reactivate the discussion on appropriate remediation or stabilization measures for such deposits and the potential for financing solutions to these problems in this most critical area of the Elbe River basin (Förstner and Salomons 2010).

\section{References}

Anon (2009/2013) Common transitory provisions for the handling of dredged material in coastal waters. August 2009, 39 p. www.htg-baggergut.de/

Förstner U (2002) Sediments and the European Water Framework Directive. J Soils Sediments 2:54

Förstner U (2015a) Dioxin and historical contaminated sediments in the Elbe river basin - II. Management Plan and Measures 2015. DOI 10.13140/RG.2.1.2771.4727, June 22, 2015; 55 p

Förstner U (2015b) Dioxin im Elbegebiet - Landesbehörde gegen den Geist der EU-Wasserrichtlinie. doi:10.13140/RG.2.1.2026.6407, May 7, 2015; $45 \mathrm{p}$

Förstner U, Salomons W (2010) Sediment research, management and policy — a decade of JSS. J Soils Sediments 10:1440-1452

Jacobs P, Krautter N, Diesner K (2013) Pollutant load reduction Spittelwasser. On demand of LAF Saxony-Anhalt, Tauw Consultants, Berlin, Germany, p 232

Mohaupt V, Irmer U, Heiss C, Rau F, Schröter-Kermani C (no date) Chemical challenges for the water management. Presentation at Ruhrverband Essen (no date), UBA Berlin, $18 \mathrm{p}$

RBC Elbe (2009) Background paper for the deduction of supra-regional management objectives - contaminant focus, FGG Elbe, Magdeburg, Germany, 02.04.2009. $29 \mathrm{p}$

RBC Elbe (2013) Sediment management concept of the RBC Elbe, FGG Elbe, Magdeburg, Germany 25.11.2013. 383 p

RBC Elbe (2014) Draft of the Actualisation of the Management Plan according to Directive 2000/60/EC for the German part of the River Basin Community Elbe for the Period 2016-2021,22.12.2014. 238 p 